\title{
Deuxième partie - Les entreprises / Présentation
}

\author{
Maurice Wolkowitsch
}

\section{CpenEdition}

\section{Journals}

Édition électronique

URL : https://journals.openedition.org/rhcf/1314

DOI : 10.4000/rhcf.1314

Éditeur

Rails \& histoire

Édition imprimée

Date de publication : 10 février 2004

Pagination : 67

ISBN : 0996-9403

ISSN : 0996-9403

Référence électronique

Maurice Wolkowitsch, « Deuxième partie - Les entreprises / Présentation », Revue d'histoire des chemins de fer [En ligne], 30 | 2004, mis en ligne le 28 août 2012, consulté le 22 avril 2022. URL : http:// journals.openedition.org/rhcf/1314; DOI : https://doi.org/10.4000/rhcf.1314

Ce document a été généré automatiquement le 22 avril 2022

Tous droits réservés 


\title{
Deuxième partie - Les entreprises / Présentation
}

\author{
Maurice Wolkowitsch
}

1 La vie des entreprises et la vie des hommes offrent des similitudes. Les compagnies de chemins de fer secondaires naissent avec l'octroi d'une concession; elles se développent éventuellement en obtenant de nouvelles concessions ou en exerçant le rôle de compagnie fermière; elles traversent des périodes fastes et néfastes, puis s'éteignent; les plus dynamiques d'entre elles ont le privilège, par rapport aux humains, de se perpétuer en se transformant et en s'adaptant. L'histoire des entreprises est d'autant plus complexe qu'elle interfère avec celle des autorités de tutelle exerçant leur pouvoir sur les territoires où se développent les réseaux.

2 Chaque entreprise, chaque ligne, chaque département, chaque ville ont leur propre histoire. L'analyse de cas concrets fait coexister en Gironde un monsieur Ortal, dont le nom apparaît trois fois comme exploitant de lignes de quelques kilomètres, et la SGCFE dont le réseau total dépassera à certaines périodes $3500 \mathrm{~km}$. Ce monde des chemins de fer secondaires est d'une extrême diversité, y distinguer des types est une démarche qui s'impose.

3 À travers leur diversité, ces entreprises ont en commun d'obéir à des règles qui les différencient des autres secteurs d'activités, à savoir leur dépendance vis-à-vis des pouvoirs publics; la question est particulièrement sensible en égard aux problèmes financiers qu'elles connaissent au cours de leur existence. Elle mérite d'être analysée. 
INDEX

Mots-clés : aménagement du territoire, chemin de fer, exploitation ferroviaire, France, infrastructure ferroviaire, politique des transports/France, chemin de fer secondaire

\section{AUTEUR}

MAURICE WOLKOWITSCH

Professeur émérite à l'université de la Méditerranée 